\title{
Impact Of Undocumented Immigration On US Wages
}

Patrick J. Reville, Iona College, USA

John E. Cullen, Mercy College, USA

\begin{abstract}
The movement of undocumented people across the southern border of the United States creates an environment which destroys the free market of United States labor by increasing the supply of labor and decreasing the price of labor. The undocumented females follow up with birth on United States soil, and create an economic dilemma for local municipalities that must provide public education for those babies. The babies become the basis within the United States for claims of citizenship activities and legalization of the original undocumented persons. In this scenario, the Law of Supply operates to decrease the earnings of unskilled labor. The Law of Supply also operates to decrease the possible unionization of unskilled workers, while decreasing governmental funds needed for municipal services. The cost to municipal governments to provide education for the anchor baby generation appears to be an unending cost increase due to the unending supply of Third World undocumented individuals crossing the United States southern borders.
\end{abstract}

Keywords: Undocumented Immigration; Labor Costs; US Wages

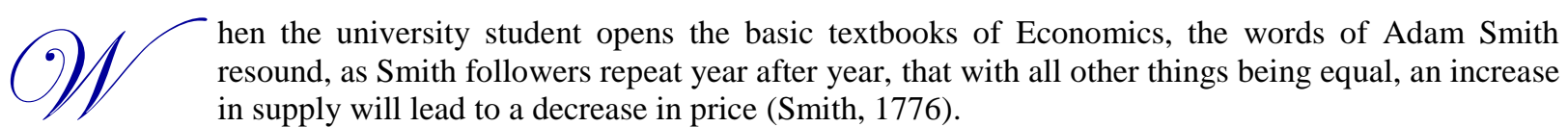
in supply will lead to a decrease in price (Smith, 1776).

When we walk across the American landscape, we find street corners and local parks filled with men waiting to be picked up by employers, and the workers are looking for an opportunity to do a day's work for a day's pay. If there are a hundred men waiting to work, the local capitalist employer realizes that he has his pick of the hundred laborers as they approach his pick-up truck. Many of the laborers feel that they are worth $\$ 10$-/hour. The capitalist employer wants to pay \$7-/hour. If the laborer refuses the work at the \$7-/hour offer, the employer will look elsewhere. The employer is aware that the free market functions well in this public park or street corner. There is no governmental presence other than "to provide for the common defense" in the form of police officers, and the free market decides the value of the labor.

The United States of America is blessed with a beautiful country with some very good neighbors in the Republic of Mexico and the Dominion of Canada. The border between the United States of America and Mexico runs from the Pacific Ocean all the way to the Gulf of Mexico, a salt water body joining with the salt waters of the Caribbean Sea. The imaginary American-Mexican border lies on the Sonora desert land mass, also known as the southern Arizona desert, and is open and porous. People can come across the desert floor in droves or by the handful, and they have been entering the United States and crossing into the State of Arizona on their way to what they consider to be a "better life" without the benefit of any governmental approval process or governmental permission. The idea expressed by Lady Liberty in New York Harbor is that America beckons to the "poor, huddled masses yearning to be free" (Lazarus, 1883). The people coming across the border are answering that call. These people are carbon copies of the waves of immigrants who preceded them. These individuals are answering the call of Lady Liberty and seeking a new life. They are escaping the poverty of their homeland. They are escaping political repression. They are seeking new opportunities in the "land of the free and the home of the brave." However, since the poem of Emma Lazarus was written (Lazarus, 1883) and displayed on a plaque on Liberty Island at the base of the Statue of Liberty in New York harbor, things have changed. Governmental interference with the flow of immigration in the name of health (Ellis Island), economics (the Chinese Exclusion Acts), and now safety 
(the Twin Towers responses such as the Patriot Act) have now made this issue a topic of front and center governmental political debate.

The Sonora desert is not just a hop, skip, and jump from northern Mexico and into the great state of Arizona. The desert during the day is mostly an unforgiving atmosphere of heat and waterless wasteland. Someone who is an experienced hiker and well prepared desert traveler is in for a treat as the elements of nature battle and push against the hiker/camper. Across the border and into this Arizona desert, come extended families of children, moms, dads, and grandparents. Mostly this is a flow of highly motivated individuals who are looking to make something better out of their lives, and nothing will stop them from moving across the desert floor. This flow of people of all sizes and all ages is an amazing sight to see. The co-author hereof witnessed this movement and personally spoke to the immigrants as they moved across from Mexico into the United States of America, particularly, into the great State of Arizona. Being from families of Irish immigrants ourselves, we may be somewhat prejudiced on this topic, and we collectively admire the risk-seeking immigrants and the new wealth of spirit that such principled and highly motivated individuals bring with them.

This immigration issue is not as simple as "the poor and huddled masses yearning to be free." The Law of Supply displays what is most obvious to us in this day and age. When you have a great amount of supply, the price will tend to go down. That is part and parcel of American capitalism as understood by American businessmen and the laborers themselves. If the supply of labor in Arizona, Utah, Nevada, and California increases with the addition of these "huddled masses," the value of that labor will go down. The price of labor per hour decreases with the addition of each immigrant crossing the border into Arizona, Texas, New Mexico, and California.

When the undocumented laborer moves across the border, the movement is normally to "al norte," to the big cities of Arizona, Nevada, and California, but America's bus companies provide cross country buses with instant access to all of the rest of the vast United States of America. As the numbers of immigrants flow into the major population centers such as Chicago, Atlanta, and New York looking for work, the Law of Supply wrecks the employment opportunities of the laborers who are already in these big cities. The inhabitants of the states and cities affected are deprived of opportunities to work and to bargain for the value of their labor in a free market. The "free" in the free market has now been slanted in favor of the employer who has an abundance of labor to pick from resulting from this immigration. The employer will look for those who will work cheaper and that is only natural in a capitalist market economy.

The price of labor is only the beginning of this undocumented labor phenomenon. Once the laborers arrive in one of the big cities and find work, any work, it is only natural that they settle down in that area. Once they settle down, the family acclimates itself to its new surroundings and children are born. The children grow and arrive at the local public school and matriculate in order to advance in America, as education is the normal ladder out of poverty and into American prosperity. Schools which are paid for by land owner taxes in states like New York provide free public education to all residents of the municipality wherein the school is situated. The public schools are free of charge to the students, and the landowning taxpayers are assessed taxes on their land and buildings, regardless of their use of the public schools. All landowners must pay the school taxes and that includes senior citizen landowners whose children have moved and do not attend the schools. The same is true of individuals who have no children, individuals whose children go to private schools, and individuals who send their children to church sponsored schools. The complaint of the landowning taxpayer is that this is a never ending flow of immigrants. The question that is posed is related to the cost of paying for education for individuals who should not even be on American soil. If the parents were not here, then the schools would not have to educate the children of the undocumented "guests." The argument from the taxpayers who provide for the public schools, is that the schools were intended for citizens and the benefit of the local society, so that an educated populace would help advance the cause of all residents of that municipality that collects the taxes from the homeowner/landowner. Can the local homeowner/landowner afford to educate the children of Third World refugees who have come to the United States without permission? Is there not a never-ending line of people that would love to get a free education for their children in the United States? This particular dilemma is a major element of discussion within municipalities across America. The flow of immigrants followed by the birth of children on American soil results in the transfer of the cost of education from Central and South American countries to the landowning taxpayers in America's municipalities. 
The issues surrounding undocumented immigrants go deeper into the economics than what is set forth herein. With just the few issues presented, should the American citizen be happy and content with the situation as is, or is there a case for righteous indignation?

The children of the undocumented immigrants are "anchor babies" due to their birth on American soil, thus being American citizens due to their place of birth, which provide an anchor for the undocumented immigrant who wants to remain the United States. The cry of "foul" attaches to the perfectly natural and blessed activity of giving birth on American soil, because many people wait for years in line to be admitted into the United States in the legally recognized manner by making applications inside their country of origin and waiting their turn. In this case, the undocumented person is here illegally in the first place and then gives birth on American soil with the claim by the person born here that he/she is an American citizen. The "anchor baby" bases its claim on the wording of the $14^{\text {th }}$ Amendment to the United States Constitution (US Constitution) and other legislation that was passed after the ratification of the $14^{\text {th }}$ Amendment. The mother and father of the "anchor baby" then base their claim to stay here because they have family in the United States, namely the "anchor baby." There is quite a bit of debate among those immigrants that waited in line and entered the United States in the normal manner. The argument can get quite heated between immigrants who have had to wait in line for years, and those who crossed the border without the wait and delay, and then proceeded to live normal law abiding lives in the United States and worked to provide for their growing families. Most Americans would say that both groups of immigrants are good solid members of the American society. However, the problem is that one group broke the law to get into the United States and the other group did not break the law. One group patiently waited their turn to enter legally, and the other group did not.

What is the basis for the argument that they can stay here? The supporters point to the $14^{\text {th }}$ Amendment. The original purpose of the $14^{\text {th }}$ Amendment to the United States Constitution was an attempt in just a few words to validate the newly freed slaves after the American Civil War (14th Amendment, 1868). The amendment was debated in the halls of the United States Congress, and the conclusion as related to the issue of American citizenship appears to be clear on its face. The language as written states that "All persons born or naturalized in the United States, and subject to the jurisdiction thereof, are citizens of the United States and of the State wherein they reside." At the time that the debate was held after the American Civil War, the recently freed slaves were the subject of the discussion (Dred Scott, 1857). Analysis of waves of illegal undocumented peoples flowing across our borders was not a topic of discussion at that point in time. We should all be aware that the idea of geographic birth deciding citizenship is not the most common of citizenship claims throughout the globe. There are many countries around the world that do not recognize a "citizen" simply due to the geography of his or her birth within the country borders (Constitution of Kuwait). Most countries require some connection to the citizenship and country of the parents before citizenship is recognized. The American Congress was acting out a form of "reconstruction" with the $14^{\text {th }}$ Amendment in 1866 (ratified 1868) after a brutal and bloody civil war. The Congress wanted to make it clear to the newly freed slave population that they were now accepted as full fledged members of this new American order. In the haste to get the job done and send the message to the rebel states and the new members of the republic, the $14^{\text {th }}$ Amendment with its language making geographic birth inside the United States of America the basis for citizenship, made the freed slaves immediate citizens by federal law. In making that point within the $14^{\text {th }}$ Amendment language, anchor babies maintain their case for citizenship. The very fact of having geographic birth within the United States apparently settles the issue of US citizenship.

The undocumented mother and father have no such argument. The unsanctioned entry over the borders remains an illegal activity. The rules say that the undocumented should not be permitted to work, and if uncovered here in America, they should be sent back to their country of origin and be placed on a blacklist of "unacceptable people" for 10 years when asking for re-entry. The undocumented includes everyone who crossed the borders without the proper paperwork, and that includes minors of all ages. The law does not distinguish as to ages of the undocumented and the law does not require intent as part of the violation of the act of crossing the border illegally. The illegal entry is a civil violation of law and is not a crime. The violation, like all other breaches of the law, cannot go unpunished.

What can be done? First of all, our nation must deal with the issue just like it deals with all other violations of the law. The people who crossed illegally must be punished with fines, deportation, or other civil penalty. The children who were brought along with their parents must be dealt with like all other children whose parents have 
violated the laws of the country. The "anchor babies" deserve some attention as well, since they were born here under a planned illegal act of improper entry.

What is to be done with these families? This is no simple matter that can be easily remedied. The best estimate is that we are talking about 15 million or more people who are undocumented and residing all across America.

Is there really any argument relative to the Law of Supply within the confines of this border crossing family? It seems obvious that with an increase in supply of labor, the price of labor will go down. Is there any argument that the arrival of these immigrants is without official documentation? It appears that they ran across the border and then settled down in search of the American dream. The original entry was illegal. However, the remainder of their American lives here indicate devotion to work and dedication to advancing their families. Most of the immigrants are stellar performers and indicative of the search for the American dream, the same dream that pushed other immigrant groups here from the beginning of the Republic after our American Revolutionary War of Independence. This fierce desire to remain here cannot be forgotten. These people, like the other waves of immigrants before them, are not afraid of work. They will do anything to provide for their families. They chose this country. They want this country to maintain its greatness. They want their children to be better off than they were. They have bought into the American dream. They make it happen every day of every week in each and every year. They love America and they respect the opportunities here for themselves and their offspring. As a country can we let this fervor, this spirit, this desire to succeed, in spite of all barriers, be removed from our country?

Despite all of the positives and the family social trauma related to their presence in this country, and the threat of deportation if uncovered and removed from the shadows, the law must be respected. We are a government of laws, not a government of men. However, we also go by the rule that the punishment must fit the "crime." The undocumented are an acquired wealth for the United States, but the act of unlawful entry cannot go "unpunished." An option of military or other government service for three years could be an alternative, plus the payment of fines and all of the taxes on the money earned while they were here illegally. Even with those penalties, they should not be given full citizenship, but rather given an identification card that permits them to work and remain in the country, while they pursue their application for valid approved entry. The benefit that they would get from coming out of the shadows would be that they can remain here with the anchor babies in the United States and continue to work and provide for their families. The undocumented, including those in the process of validation, should not be given access to any government programs providing services.

\section{AUTHOR INFORMATION}

Patrick J. Reville, Esq., B.B.A., J.D., is a Professor of Business Law in the Hagan School of Business at Iona College, New Rochelle, New York, and in private practice of Accounting and Law in New Rochelle, N.Y. E-mail: preville@iona.edu (Corresponding author)

John E. Cullen, Esq., is a Professor of the School of Business, Mercy College, Dobbs Ferry, New York, as well as a practicing bilingual, Spanish/English, accountant/attorney with a private practice in the New York metropolitan area. Professor Cullen was honorably discharged from the United States Marine Corps and served honorably with the United States Peace Corps, Venezuela.

\section{REFERENCES}

1. Chinese Immigration Act of 1923. Chinese excluded from America by federal law.

2. Dred Scott vs Sandford. 60 U.S. 393. (United States Supreme Court, 1857). People of African descent were not protected by the Constitution and were not citizens.

3. Ellis Island. A Federal immigrant inspection station, situated in New York Harbor and open for business from 1892 until 1954, which is believed to have processed 12 million immigrants, the first of which was Annie Moore, a 15 year old girl from Ireland.

4. Constitution of Kuwait. If a Kuwaiti citizen gives birth, the child is born a citizen of Kuwait; with other births in Kuwait, the child is a citizen of the parents' home country. 
5. Lazarus, Emma. The New Colossus. (1883) This poem is mounted on a plaque at the entrance to the Statue of Liberty in New York City Harbor (1903) in the federal park on Liberty Island, reachable by ferry from lower Manhattan specifically in Battery Park. Lady Liberty proclaims: "Keep, ancient lands, your storied pomp!" cries she with silent lips. "Give me your tired, your poor, Your huddled masses yearning to breathe free, The wretched refuse of your teeming shore. Send these, the homeless, tempest-tossed to me."

6. Patriot Act, passed by the United States Congress and made law October 26, 2001- anti-terrorist laws.

7. Smith, Adam. An Inquiry into the Wealth of Nations. (1776).

8. United States Constitution. $14^{\text {th }}$ Amendment. (1868) Section 1. All persons born or naturalized in the United States, and subject to the jurisdiction thereof, are citizens of the United States and of the State wherein they reside. 


\section{NOTES}

